Scientific Journal Warsaw University of Life Sciences - SGGW

Problems of World Agriculture volume 19 (XXXIV), number 3, 2019: 46-56 DOI: 10.22630/PRS.2019.19.3.45

Anna Sylwia Kowalska, ${ }^{1}$ Klaudia Gurkowa ${ }^{2}$

Wroclaw University of Economics and Business, Poland

\title{
Changes in Potato Production and Consumption in Poland in 2001-2019
}

\begin{abstract}
The aim of the article is to analyse and assess changes in the potato market in Poland. The area of potato cultivation in Poland is gradually decreasing. The scale of this phenomenon is very large - unparalleled in any other country. Unprocessed, fresh potato are replaced more and more often with ready-made preserves and cereal products, e.g. groats, rice and pasta. The study uses statistical materials published by The Institute of Agricultural and Food Economics - National Research Institute and the Central Statistical Office. The time range of these data covers the years 2001-2019. During the development of the data, the basic methods of statistical analysis were used, i.e. correlation, change dynamics, arithmetic mean and standard deviation.
\end{abstract}

Key words: potato, production, consumption, evolution

JEL Classification: F1, F14, Q02, Q13, Q17, P32

\section{Introduction}

Rice, wheat and potato - this is how the three most-popular basic foods in the world are presented. Times change, trends follow each other at dizzying pace and the food pyramid undergoes constant modifications. Transitions take place on all continents (Dzwonkowski, 2017). It would seem that they do not concern Poland directly. However, it is different. All kinds of factors, with varying impact, come from all over the world. As a result, they strongly interfere with what is happening on the local economic market.

For years, Poland has been the leader of the top potato producers in Europe (Pedersen et al., 2005). Cultivated since the nineteenth century, potato appeared in the country already under the reign of King Jan III Sobieski. He gave it to his beloved Marysieńka as a decoration of the garden. It is not surprising then that in the Polish tradition it is difficult to imagine a real dinner without potato. Cooked, served with butter or dill, mashed, roasted, in the form of purees, fries, chips or boiled and served with cottage cheese, and also processed into the feed - there are many ways of using them and all considered equally valuable.

Potato has become a type of food so common, that often underestimated. However, they have many nutritional values that have a good effect on the human health. They are easily digestible and low in calories. They contain approx. $77 \mathrm{kcal}$ per $100 \mathrm{~g}$. They abound in potassium which lowers blood pressure and magnesium which in turn is the basic building block of bones and teeth. Thanks to this, they help to relieve the symptoms of fatigue and stress. They contain fibre and thus support metabolic processes and lower cholesterol levels. Moreover, they are also a valuable source of vitamin C (Zarzyńska et al.,

\footnotetext{
${ }^{1}$ dr hab. inż., prof. UE, ul. Komandorska 118/120, 53-345 Wrocław, e-mail: anna.kowalska@ue.wroc.pl; https://orcid.org/0000-0002-8472-8386

${ }^{2}$ mgr inż., Graduate of the Wroclaw University of Economics and Business, ul. Komandorska 118/120, 53-345 Wrocław, e-mail: klaudia.gurkowa@op.pl; https://orcid.org/0000-0001-5979-7753
} 
2016). However, it should be noted that the largest amounts of it occur in early potato varieties. The more time passes from the harvesting and the longer the potato are stored in basements, mounds or stores, the more yellow colour the tubers acquire and the content of this ingredient decreases (Czerko, 2015). It does not change the fact, however, that by eating potato regularly, the level of most minerals in the body gets supplemented.

According to IHAR-PIB data, the area of potato cultivation in Poland is gradually decreasing. The scale of this phenomenon is very large - unparalleled in any other European country. In the 1960s, potato in Poland occupied an area of 2.8 million ha, which accounted for $18.8 \%$ of the cropping patterns (GUS, 2019). The amount of potato harvest (at that time estimated at 50 million tons per year) located Poland on the second place in the world, just behind the USSR (Petrick, Weingarten, 2004). Poland has been ranked seventh in the world and the percentage share in global production in 2016 amounted to $2.35 \%$ (Potato market ... 2019). Among European countries, only our eastern neighbours: Ukraine and Belarus produce more potato (Tuka, 2016). Poland, among EU countries, in 2017, in terms of production, this plant was ranked second (9.17 million tons), just behind Germany (11.72 million tons). The share of potato harvest from Poland accounted for $15 \%$ of EU harvests, while from Germany 19.1\%. Although in 2017 the area for potato cultivation in Poland was the largest (329 thousand ha) among EU countries, the yield per hectare (27.9 tons/ha) was below the EU average (35.2 tons/ha). The highest amount of harvest per hectare had such EU countries like Belgium (47.6 tons/ha), Germany (46.7 tons/ha) and the Netherlands (46.0 tons/ha). Poland was ranked only 16th (GUS, 2018b).

As of today, much less potato is distributed in Poland, as it is 7.7 million tons. The biggest change has taken place in the industrial processing sector. Unprocessed, fresh potato are frequently replaced with ready-made products and cereal products, e.g. groats, rice, pasta (Szajner, 2018). This is due to changes in the lifestyle and decrease in the quality of the potato itself (Commission of the European Communities, 2007). As a result, this vegetable, once considered to be cheap, is definitely less often served on Polish tables now.

In order to improve this situation, the Ministry of Agriculture and Rural Development developed in September 2018 the Polish Potato Program, which is expected to take effect from 2020. Its main purpose is to help to professionalize the sector of crops of this vegetable, traditionally important in Poland.

Potato plantations in Poland are attacked by numerous pests, among which diseases caused by quarantine organisms are of great phytosanitary importance, one of these diseases is potato ring rot. This disease significantly affects the quality of the plant, which means that it does not meet the phytosanitary requirements of the European Union, due to which its production capacity is at high risk (Klusek, 2019).

Poland is not the only country that has a problem with this bacterium. In Europe, the disease was widespread throughout Scandinavia. It is more severe in the Baltic Countries (Estonia, Lithuania, Latvia) and in Germany, Poland, Russia, the Czech Republic, Ukraine and Belarus. Occasionally, disease outbreaks have been detected in Austria, Belgium, France, the Netherlands and Slovakia. In Denmark, Finland and Sweden the disease was eradicated in the seed system, but it still occurs sporadically in the crop production, while in Germany since 2000 the detectability of the disease has been systematically reduced in both seed and commodity potato. Countries currently considered free of this pathogen include: Italy, Ireland, Luxembourg, Portugal, Romania and Slovenia (Pastuszewska, Pawlak, 2006).

The Ministry of Agriculture and Rural Development (MRiRW) has taken action to make full use of the potato production potential. It assumes complete elimination of the bacteria 
Clavibacter michiganesis ssp. Sepedonicus, hence the greater impact of this raw material on European Union markets, and ultimately, better profitability of crops, i.e. increase in profit from sales and development of the potato market in Poland (MRiRW, 2018). The aim of the article is to analyse and assess changes in the potato market in Poland.

\section{Data and methods}

The study uses statistical materials published by The Institute of Agricultural and Food Economics - National Research Institute (IERiGZ̈-BIP) and the Central Statistical Office (GUS) in Poland. The basic time range of these data covers the years 2001-2019.

The elaboration of data used basic methods of statistical analysis, among others, the correlation between the area of crops and yield per hectare as well as indicators of dynamics of changes in the area, yield and harvest of potato were calculated. In order to show the changes (in 2001-2017), the arithmetic mean and standard deviation were used in the area of crops, harvest and yield in individual voivodeships.

\section{Area of crops, harvest and yield of potato in Poland}

The area of potato cultivation in Polish farms was in 2018 approximately 316 thousand ha which accounted for $2.7 \%$ of the total crop area. The area of potato cultivation decreased in relation to 2001 by 878 thousand ha, i.e. $73.5 \%$ (Figure 1). The trend line shows that this tendency was present throughout the entire period under consideration, a slight increase in the crop area was visible in 2015-2017. In the analysed period, the area of potato cultivation in Poland was reduced every year on average by 37 thousand ha with a very good adjustment of the trend line $\left(\mathrm{R}^{2}=0.79\right)$. The size of potato harvests also shows a decreasing trend during the period under consideration. In 2018, potato harvest amounted to less than 9 million tons, while in 2001. it was almost 20 million tons. During the period considered, it decreased by over 10.5 million tons (i.e. almost 55\%). On average, this decline was at the level of 0.46 million tons a year, with a good adjustment of the trend line $\left(\mathrm{R}^{2}=0.64\right)$.

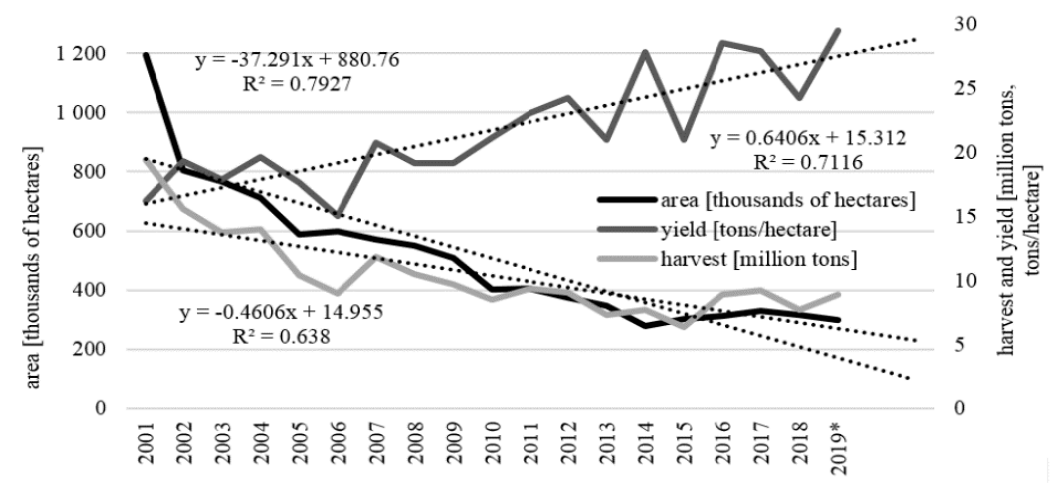

Fig. 1. Changes in crop area, harvest and yield of potato in Poland in 2001-2019 [thousands of hectares, million tons, tons / hectare]

Source: own study based on Local Data Bank and Potato Market. Status and prospects (2001-2018). Market analyses by IERiGŻ-BIP, MRiRW, ARR. 
The increase in potato crop area in 2015-2017 and harvest in 2016-2017 was a positive phenomenon breaking the long-term tendency of a significant decrease in the area and harvest of this species. According to experts, the reason for the increase in the area was, among others, greater demand for potato raw material in the starch industry, as well as the dynamic development of the food industry in Poland. Area payments for the cultivation of starch potato is also an incentive for many farmers to specialize in this type of production (Plichta, 2019).

The analysis of data on yield in 2001-2018 showed growing tendency. In 2018. from one hectare of cultivated area, an average of 24.2 tons of potato was harvested, while in 2001 . it was 16.2 tons, which means an increase by over $82 \%$. The average annual increase in yields in the analysed period amounted to 0.64 tons/ha, with the adjustment of the trend line at the level of $\mathrm{R}^{2}=0.71$.

The declining trend in the area for growing potato and increasing tendency in the case of yield per hectare in Poland in 2001 - 2018 were very well correlated (Fig. 2). The correlation value in the examined period in the case of crop area and yield per hectare was strongly negative (-0.72). This means that the yield per hectare in the analysed period has significantly improved, which is definitely affected by weather conditions and plant protection products used by farmers.

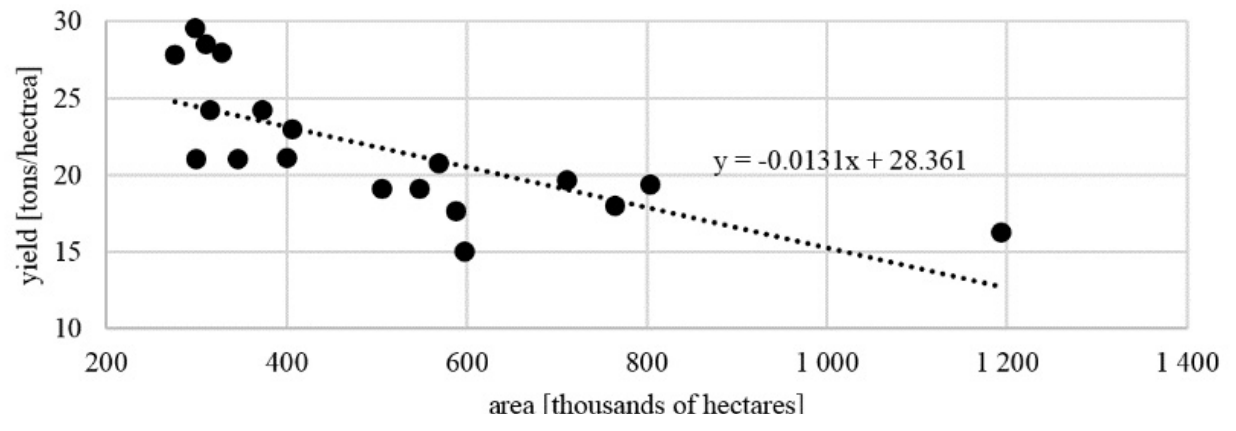

Fig. 2. Correlation between potato area and yield per hectare in Poland in 2001-2018

Source: own study based on Local Data Bank and Potato Market. Status and prospects (2001-2018). Market analyses by IERiGŻ-BIP, MRiRW, ARR

One of the most important key decisions on potato yielding is to optimal water supply during the growing season (Dzieżyc, 1989). In Poland, irrigation is still not used on potato plantations, and drought during the growing season significantly affects their yielding (Nowacki, 2018). Potato is a species whose water needs during the growing season are quite high (350-450 $\mathrm{mm}$ of precipitation in the period from April to September) but if its high productivity (up to $80-100$ tons/ha of fresh tuber) is taken into account, then the transpiration coefficient in comparison for other crop species is quite low (about 2001 of water $/ \mathrm{kg}$ in fresh yield). This fact puts the potato among the most effective plant species in terms of water use efficiency in yield accumulation (Haverkort, Mackerron, 2000; Nowacki, 2018). 


\section{Changes in the crop area, harvest and yield in individual voivodeships}

The assessment of differences in the area of potato crops in individual voivodships was made on the basis of arithmetic mean and standard deviation. The analysis of the data from table 1 showed that the area of potato crops in individual voivodships, during almost the entire period considered, qualified them to the same group. Five groups of voivodeships with a similar crop area of were isolated (from 3 to -2 ).

Table 1. Changes in potato cultivation area by voivodships in 2001-2017

\begin{tabular}{|c|c|c|c|c|c|c|c|c|c|c|c|c|c|c|c|c|c|}
\hline Voivodeships & ஓ্ণ & 용 & 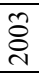 & ষ্ণ & 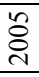 & $\begin{array}{l}\text { ○ } \\
\text { ᄋ }\end{array}$ & 용 & 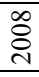 & 용 & $\begin{array}{l}\stackrel{0}{0} \\
\text { ㅇ }\end{array}$ & $\bar{\nabla}$ & 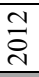 & $\frac{m}{\stackrel{n}{d}}$ & $\stackrel{ \pm}{\stackrel{D}{\circ}}$ & $\frac{n}{\circ}$ & $\frac{0}{\circ}$ & 공 \\
\hline Mazowieckie & 3 & 3 & 3 & 3 & 3 & 3 & 3 & 3 & 3 & 3 & 2 & 2 & 3 & 3 & 2 & 2 & 2 \\
\hline Łódzkie & 2 & 2 & 2 & 2 & 2 & 2 & 2 & 2 & 1 & 2 & 2 & 2 & 2 & 3 & 2 & 2 & 2 \\
\hline Wielkopolskie & 1 & 1 & 1 & 2 & 2 & 1 & 1 & 1 & 1 & 2 & 2 & 2 & 2 & 3 & 2 & 2 & 2 \\
\hline Podkarpackie & 1 & 1 & 1 & 1 & 1 & 1 & 1 & 1 & 1 & 1 & 1 & 1 & 1 & 1 & 1 & 1 & 1 \\
\hline Małopolskie & 1 & 1 & 1 & 1 & 1 & 1 & 1 & 1 & 1 & 1 & 1 & 1 & 1 & 1 & 1 & 1 & 1 \\
\hline Lubelskie & 1 & 1 & 1 & 1 & 1 & 1 & 1 & 1 & 1 & 1 & 1 & 1 & 1 & 1 & 1 & 1 & 1 \\
\hline Kujawsko-Pomorskie & -1 & -1 & -1 & -1 & -1 & -1 & -1 & -1 & -1 & -1 & -1 & -1 & -1 & -1 & -1 & 1 & 1 \\
\hline Dolnośląskie & -1 & -1 & -1 & -1 & -1 & -1 & -1 & -1 & -1 & -1 & -1 & 1 & -1 & -1 & 1 & 1 & -1 \\
\hline Pomorskie & -1 & -1 & -1 & -1 & -1 & -1 & -1 & -1 & -1 & -1 & -1 & 1 & -1 & 1 & -1 & -1 & -1 \\
\hline Świętokrzyskie & -1 & -1 & -1 & -1 & -1 & -1 & -1 & -1 & -1 & -1 & -1 & -1 & -1 & -1 & -1 & -1 & -1 \\
\hline Zachodniopomorskie & -1 & -1 & -1 & -1 & -1 & -1 & -1 & -1 & -1 & -1 & -1 & -1 & -1 & -1 & -1 & -1 & -1 \\
\hline Podlaskie & -1 & 1 & 1 & -1 & -1 & -1 & -1 & -1 & -1 & -1 & -1 & -1 & 1 & -1 & -1 & -2 & -1 \\
\hline Śląskie & -1 & -1 & -1 & -1 & -1 & -1 & -1 & -1 & -1 & -1 & -1 & -2 & -2 & -1 & -2 & -2 & -1 \\
\hline Opolskie & -1 & -2 & -2 & -2 & -2 & -2 & -2 & -2 & -1 & -2 & -2 & -1 & -2 & -2 & -2 & -1 & -2 \\
\hline Warmińsko-Mazurskie & -1 & -1 & -1 & -1 & -2 & -1 & -2 & -2 & -2 & -1 & -2 & -2 & -1 & -2 & -1 & -2 & -2 \\
\hline Lubuskie & -2 & -2 & -2 & -2 & -2 & -2 & -2 & -2 & -2 & -2 & -2 & -2 & -2 & -2 & -2 & -2 & -2 \\
\hline
\end{tabular}

Source: own study based on data from the Local Data Bank.

The first group of voivodships, which in the entire analysed period showed the biggest potato crop area, within the scope of two, and in 2001-2010 and 2014 even three standard deviations from the average, consisted of Mazowieckie voivodship. Since 2010, a similar acreage for cultivation of potato like in Mazowieckie voivodship has been noted in Łódzkie and Wielkopolskie voivodships. The next group of voivodships, where the area for potato cultivation was above the national average, however lower than in the group of leaders, included Podkarpackie, Małopolskie and Lubelskie voivodeships. In these voivodships, the crop area in the entire analysed period was above the national average by one standard deviation. Another group of voivodships, in which the crop area in the entire considered period (with few exceptions, when it was one standard deviation above the national average) was below the national average to minus one standard deviation (-1), consisted of the following voivodeships: Kujawsko-Pomorskie, Dolnośląskie, Pomorskie, Świętokrzyskie, Zachodniopomorskie, Podlaskie and Śląskie. In the case of Ślaskie voivodeship, there is a tendency for farmers to limit the area for potato cultivation, which is especially visible in 2012-2013 and 2015-2016. The last group of voivodships, in which the average area of cultivation in the studied period was two standard deviations below the average in Poland (-2) included Opolskie, Warmińsko-Mazurskie and Lubuskie voivodships where the area of potato crops was by two standard deviations lover than the national average in the entire analysed period. 
The assessment of changes in potato harvests has shown that also in case of harvest, voivodships can be divided into 5 groups (from 3 to -2), (Table 2). In the case of harvests, as in the case of the crop area, Mazowieckie voivodeship took first place in the analysed period. The largest harvest, three standard deviations above the national average, Mazowieckie voivodship achieved in 2001-2004, 2006-2010 and 2013. In the last studied year, i.e. 2017, Wielkopolski voivodeship was the leader in this respect, in which as the potato harvest there was higher than the national average by as much as three standard deviations. In previous years, they were volatile and ranged from one (in 2001-2003 and 2006-2008) to two standard deviations (in 2004-2005 and 2009-2016). In contrast, in Łódzkie voivodship throughout the entire analysed period (excluding 2006), potato harvest was higher than the national average by two standard deviations. Another group of similar voivodeships included Podkarpackie, Lubuskie and Małopolskie voivodeships. In these voivodships, the harvests (excluding Podkarpackie voivodship in 2014 and he Małopolskie voivodship in 2001, 2013 and 2017) were higher than the national average by one standard deviation. Since 2015, this group has been joined by Kujawsko-Pomorskie voivodeship. The next group, in which the potato harvest was in most of the surveyed period below the national average by one standard deviation, included Pomorskie, Dolnośląskie, Świętokrzyskie, Zachodniopomorskie and Podlaskie voivodeships. In 2016, it was joined by Opolskie voivodeship. The last group are the voivodeships with the lowest potato harvest, in most of the studied period the harvest there was lower than the average even by two deviations. This group included Lubuskie and Warmińsko-Mazurskie voivodeships which since 2015 have been permanently accompanied by Śląskie voivodeship.

Table 2. Changes in potato harvests by voivodships in 2001-2017

\begin{tabular}{|c|c|c|c|c|c|c|c|c|c|c|c|c|c|c|c|c|c|}
\hline Voivodeships & $\overrightarrow{\mathrm{d}}$ & 용 & 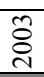 & 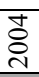 & 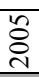 & ๖ & 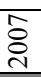 & $\begin{array}{l}\infty \\
\stackrel{ᄋ}{\odot} \\
\stackrel{\sim}{\nu}\end{array}$ & 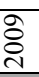 & $\stackrel{\circ}{\stackrel{\circ}{\circ}}$ & $\vec{\Xi}$ & $\frac{N}{d}$ & $\stackrel{m}{\stackrel{n}{\sigma}}$ & $\stackrel{ \pm}{\stackrel{D}{d}}$ & $\stackrel{n}{\circ}$ & $\stackrel{0}{\stackrel{0}{\circ}}$ & $\stackrel{\bar{\sigma}}{\bar{\delta}}$ \\
\hline Wielkopolskie & 1 & 1 & 1 & 2 & 2 & 1 & 1 & 1 & 2 & 2 & 2 & 2 & 2 & 2 & 2 & 2 & 3 \\
\hline Mazowieckie & 3 & 3 & 3 & 3 & 2 & 3 & 3 & 3 & 3 & 3 & 2 & 2 & 3 & 2 & 2 & 2 & 2 \\
\hline Łódzkie & 2 & 2 & 2 & 2 & 2 & 1 & 2 & 2 & 2 & 2 & 2 & 2 & 2 & 2 & 2 & 2 & 2 \\
\hline Podkarpackie & 1 & 1 & 1 & 1 & 1 & 1 & 1 & 1 & 1 & 1 & 1 & 1 & 1 & 2 & 1 & 1 & 1 \\
\hline Lubelskie & 1 & 1 & 1 & 1 & 1 & 1 & 1 & 1 & 1 & 1 & 1 & 1 & 1 & 1 & 1 & 1 & 1 \\
\hline Małopolskie & -1 & 1 & 1 & 1 & 1 & 1 & 1 & 1 & 1 & 1 & 1 & 1 & -1 & 1 & 1 & 1 & -1 \\
\hline Kujawsko-Pomorskie & -1 & -1 & -1 & -1 & -1 & -1 & -1 & -1 & -1 & -1 & -1 & -1 & -1 & -1 & 1 & 1 & 1 \\
\hline Pomorskie & -1 & -1 & -1 & -1 & -1 & -1 & -1 & -1 & 1 & -1 & -1 & 1 & 1 & 1 & 1 & 1 & -1 \\
\hline Dolnośląskie & -1 & -1 & -1 & -1 & -1 & -1 & -1 & -1 & -1 & -1 & 1 & 1 & 1 & -1 & 1 & 1 & -1 \\
\hline Świętokrzyskie & -1 & -1 & -1 & -1 & -1 & -1 & -1 & -1 & -1 & -1 & -1 & -1 & -1 & -1 & -1 & -1 & -1 \\
\hline Zachodniopomorskie & -1 & -1 & -1 & -1 & -1 & -1 & -1 & -1 & -1 & -1 & -1 & -1 & -1 & -1 & -1 & -1 & -1 \\
\hline Podlaskie & -1 & 1 & -1 & -1 & -1 & -1 & -1 & -1 & -1 & -1 & -1 & -1 & -1 & -1 & -2 & -2 & -1 \\
\hline Opolskie & -1 & -2 & -2 & -2 & -2 & -2 & -2 & -1 & -1 & -1 & -1 & -1 & -2 & -1 & -2 & -1 & -1 \\
\hline Śląskie & -1 & -1 & -1 & -1 & -1 & -1 & -1 & -1 & -1 & -2 & -1 & -2 & -2 & -1 & -2 & -2 & -2 \\
\hline Warmińsko-Mazurskie & -1 & -1 & -1 & -2 & -2 & -2 & -2 & -2 & -2 & -1 & -2 & -2 & -1 & -2 & -2 & -2 & -2 \\
\hline Lubuskie & -2 & -2 & -2 & -2 & -2 & -2 & -2 & -2 & -2 & -2 & -2 & -1 & -2 & -2 & -2 & -2 & -2 \\
\hline
\end{tabular}

Source: own study based on the Local Data Bank.

A characteristic feature of the climate prevailing in our country is the large regional diversity in terms of rainfall distribution. Some regions of Poland are characterized by chronic rainfall deficit (Bulletin of IMGW 1983-2017). The rainfall deficit in the growing season of potato tubers causes yield losses to reach $10-50 \%$, and in extreme cases even 50$70 \%$. It is assumed that if Polish farmers do not start irrigating their plantations, the phenomenon will grow in the future. Potato is a species in case of which not only the yield 
but also its quality is important and without irrigation to protect the optimal soil moisture, potato production will not be possible. Poor soil moistening during the growing season, apart from the reduction in yield, causes the defects of tuber appearance (size reduction, deformations, cracking, secondary growth, skin diseases, internal flaws, etc.) or deterioration of technological value (dry mass, starch, sugar content, etc.) (Głuska, 2002; Nowacki, 2008).

The analysis of changes in potato yields showed that in the analysed period they were different in individual voivodships, as opposed to the area and harvest (Table 3). In the case of yield per hectare, the deviation from the average in the country (depending on the year) ranged from 3 to -3 .

Table 3. Changes in potato yield by voivodships in 2001-2017

\begin{tabular}{|c|c|c|c|c|c|c|c|c|c|c|c|c|c|c|c|c|c|}
\hline Voivodeships & 휴 & రి & 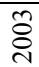 & ঠి & $\stackrel{\overbrace{}}{\stackrel{\overbrace{}}{\circ}}$ & 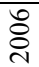 & $\stackrel{\text { }}{\stackrel{8}{\circ}}$ & $\stackrel{\infty}{\stackrel{0}{\circ}}$ & $\stackrel{\text { }}{\stackrel{\text { }}{0}}$ & $\stackrel{\circ}{\stackrel{0}{\circ}}$ & $\bar{\Xi}$ & $\frac{\mathfrak{d}}{\stackrel{\sim}{d}}$ & $\stackrel{m}{\stackrel{n}{\sigma}}$ & $\underset{\sim}{\stackrel{\Xi}{\sim}}$ & $\frac{n}{\stackrel{n}{c}}$ & $\stackrel{\circ}{\stackrel{\sim}{\circ}}$ & $\frac{\Gamma}{\stackrel{\nu}{~}}$ \\
\hline Opolskie & 1 & 2 & 1 & 1 & 2 & 2 & 2 & 3 & 1 & 2 & 3 & 3 & 2 & 2 & 1 & 2 & 2 \\
\hline Dolnośląskie & 1 & 1 & -1 & 2 & 2 & 1 & 2 & 1 & 1 & -1 & 1 & 2 & 2 & 1 & -1 & -1 & 2 \\
\hline Zachodniopomorskie & 1 & 1 & 1 & 2 & 2 & 1 & -1 & 2 & 2 & 1 & 1 & 1 & 1 & 1 & 3 & 2 & 1 \\
\hline Pomorskie & -1 & 3 & 2 & 1 & 1 & 2 & 1 & 2 & 2 & 2 & 1 & 1 & 1 & 1 & 2 & 1 & 1 \\
\hline Kujawsko-Pomorskie & 1 & 1 & 2 & 2 & -1 & 1 & 2 & -1 & 1 & 1 & 1 & 1 & 1 & -1 & 2 & 1 & 1 \\
\hline Lubelskie & -1 & -1 & -1 & -1 & -1 & 1 & -1 & 1 & -1 & 2 & 1 & -1 & 1 & -1 & 1 & 1 & 1 \\
\hline Lubuskie & 2 & 1 & -2 & 1 & 1 & -2 & -1 & -1 & -1 & -1 & -1 & 1 & 1 & 1 & -1 & 1 & 1 \\
\hline Wielkopolskie & 2 & -1 & -1 & 1 & -1 & 1 & 1 & -2 & 2 & 1 & 1 & 2 & 2 & -1 & -1 & 1 & 1 \\
\hline Łódzkie & -2 & -2 & -2 & -1 & -2 & -1 & 2 & -1 & 1 & -1 & 1 & 1 & -1 & 1 & -1 & 1 & -1 \\
\hline Podkarpackie & -1 & 1 & 1 & -2 & -2 & 1 & -1 & -1 & -1 & -1 & -2 & -1 & -1 & 1 & 1 & -1 & -1 \\
\hline Mazowieckie & 1 & -1 & -1 & -1 & -2 & -2 & -1 & -1 & -2 & 1 & -1 & -1 & -1 & -2 & -1 & -1 & -1 \\
\hline Warmińsko-Mazurskie & 1 & -1 & 2 & -1 & -1 & 1 & -1 & 1 & -1 & 1 & -1 & -2 & -1 & -1 & -1 & -1 & -1 \\
\hline Podlaskie & 1 & -1 & -1 & -1 & -1 & -1 & -1 & -1 & -2 & -1 & -2 & -2 & -1 & -2 & -2 & -2 & -1 \\
\hline Świętokrzyskie & -2 & -2 & -1 & -2 & -1 & -1 & -2 & -1 & -1 & -2 & -2 & -2 & -2 & -1 & 1 & -1 & -2 \\
\hline Śląskie & -1 & 1 & 1 & -1 & 2 & -1 & 1 & 1 & 1 & -2 & -1 & -1 & -2 & 1 & -2 & -1 & -2 \\
\hline Małopolskie & -2 & -1 & -1 & -2 & -1 & -1 & -2 & -2 & -2 & & -2 & -1 & -2 & -1 & -1 & -2 & -2 \\
\hline
\end{tabular}

Source: own study based on the Local Data Bank.

Six groups were distinguished, however, the voivodeships belonging to them significantly differed from those distinguished due to the area of crops and harvest. In 2017, only four groups of voivodships occurred. The largest yield per hectare, by two standard deviations above the average, showed Opolskie and Dolnoślaskie voivodships, located in the first group. Opolskie voivodeship, in the entire analysed period, both in the case of area and harvest, showed values always below the national average, while the yield per hectare there, although variable, was always above the national average value. The second group consisted of voivodships in which in 2017 yield per hectare was higher by one deviation than the average, these were the following voivodeships: Zachodniopomorskie, Pomorskie, Kujawsko-Pomorskie Lubelskie, Lubuskie and Wielkopolskie. In this group of voivodships, high yields per hectare, in almost the entire considered period above the average in the country was noted in Zachodniopomorskie voivodship (excluding 2007 - when it was below the average, and in 2015 even three deviations above the average) and Pomorskie (excluding 2001 - when it was below average, and in 2002 three deviations above the average). Another group of voivodships, in the last year below the national average by one standard deviation, covered Łódzkie, Podkarpackie, Mazowieckie, Warmińsko-Mazurskie as well as Podlaskie voivodeships. Mazowieckie voivodship, which was the leader in the area and harvest, in the case of yields was ranked, in the entire analysed period, below the national average by one and in the years 2005-2006, 2009 and 2014 even by two 
standard deviations. Łódzkie voivodeship also had very poor yields per hectare, and similarly to Mazowieckie, it was located in the first group in the case of area and harvest. The last group of voivodships includes Świętokrzyskie, Śląskie and Małopolskie, where crops in 2017 were lower than the national average by two standard deviations and in the case of Małopolskie voivodship in 2010 it was even by three deviations lower.

\section{Potato consumption in Polish households}

Numerical analysis illustrating the balance of potato consumption in Poland over the period 2000/2001 - 2018/2019 testify to the long-term downward trend in the consumption of potato (Fig. 3). In the analysed period, the total consumption of potato decreased by over $30 \%$, i.e. by 1.56 million tons (from 5.11 million tons in the $2000 / 2001$ season to 3.55 million tons in 2018/2019). On a yearly average, in the years 2000/2001-2018/2019, it was a decrease by almost 90 thousand tons $\left(\mathrm{R}^{2}=0.98\right)$. In the $2000 / 2001$ season, in the structure of potato consumption, unprocessed potato accounted for over $91 \%$, whereas potato products $-8.6 \%$. In 2018. the consumption structure of individual product groups changed. Currently, in the structure of consumption, unprocessed potato account for $3 / 4$ of total potato consumed, while potato products for remaining $1 / 4$. At the same time, it is worth noting that the population did not completely give up this vegetable. The decrease in the consumption of potato is associated only with the limitation of its consumption in the unprocessed form. Currently, the consumption of potato in pure form has been replaced with ready-made products that are their derivatives (Commission of the European ..., 2007). This means that despite all kinds of evolution of eating habits and cost reforms, the potato remains in the Polish cuisine.

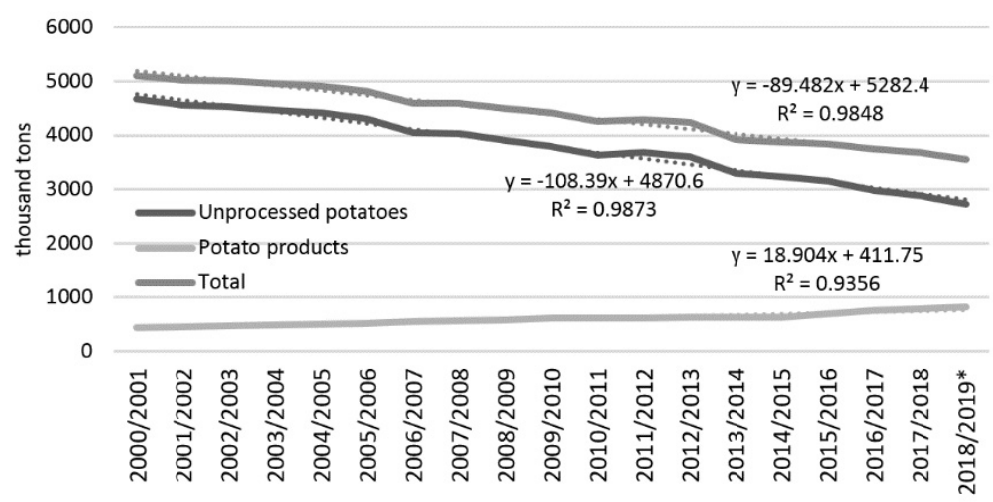

Fig. 3. Potato consumption in Poland in the years 2000 / 2001-2018 / 2019 (in thousands of tons)

Source: Potato market. Status and prospects (2001-2018). Market analyses by IERiGŻ-BIP, MRiRW, ARR.

In the analysed period, the consumption of fresh potato decreased by over $41 \%$, i.e. by 1.94 million tons, while the consumption of potato products increased by over $86 \%$. On a yearly average, the consumption of fresh potato declined by over 108 thousand tons $\left(\mathrm{R}^{2}=0.99\right)$, while the consumption of potato products increased by almost 19 thousand tons per year $\left(\mathrm{R}^{2}=0.93\right)$. Based on the above analyses, it can be expected that this trend will continue. The increase in the consumption of potato products resulted from such 
phenomena as: changes in the lifestyle of Polish society, price fluctuations and the availability of new products on the food market (GUS, 2018a).

Data analysis of potato consumption per capita showed that in the 2017/2018 season potato consumption decreased by $1.3 \mathrm{~kg}$ to $96 \mathrm{~kg} /$ person. In the season 2018/2019, the downward trend in the consumption of potato is expected to be maintained at the level estimated at $92.3 \mathrm{~kg} /$ person. Over last 18 years, the consumption of this vegetable decreased by more than $31 \%$. The average annual decrease in potato consumption at that time was $2.4 \mathrm{~kg} /$ person. A very good fit of the trend line $\left(\mathrm{R}^{2}=98\right)$ indicates that this trend will continue in the following years. The decrease in potato consumption is connected, as already mentioned, with the limitation of consumption of this vegetable in an unprocessed form.

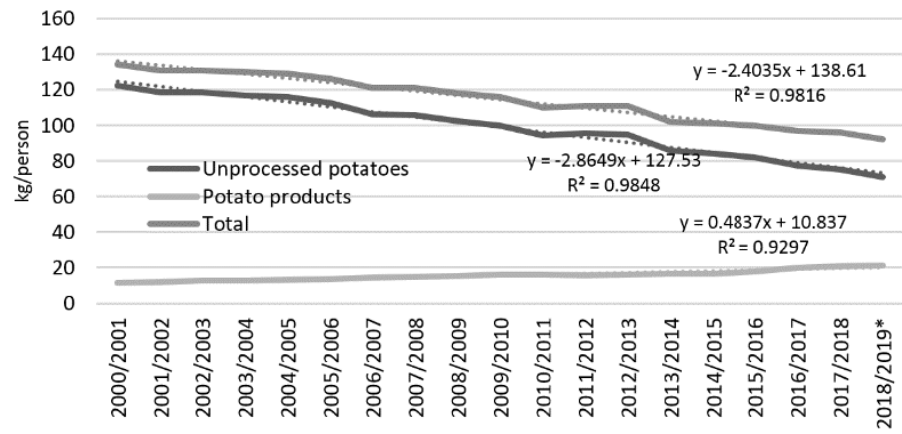

Fig. 4. Potato consumption in Poland in 2000/2001-2018/2019 (kg/person)

Source: Potato market. Status and prospects (2001-2018). Market analyses by IERiGŻ-BIP, MRiRW, ARR.

The analysis of the data showed that the consumption of fresh potato in the 2017/2018 season was $75.2 \mathrm{~kg} /$ person, while in the $2000 / 2001$ season it used to be $122.3 \mathrm{~kg} / \mathrm{person}$ (a decrease by almost $42 \%$ ). The average annual decrease in fresh potato consumption over 18 years, with a very good adjustment of the trend line $\left(\mathrm{R}^{2}=98\right)$, is almost $3 \mathrm{~kg} /$ person. However, the consumption of processed potato products increases. In the analysed period, it increased by over $85 \%$ (from $11.5 \mathrm{~kg} /$ person in the $2000 / 2001$ season to $20.8 \mathrm{~kg} / \mathrm{person}$ in the 2007/2018 season). Forecasts assume that in the next season, i.e. 2018/2019, the upward trend will continue and the consumption of processed potato products will increase to $21.3 \mathrm{~kg} / \mathrm{person}$. The average annual growth in consumption of potato products is almost $0.5 \mathrm{~kg} /$ person $\left(\mathrm{R}^{2}=0.93\right)$.

\section{Summary}

The analysis of changes in potato production in Poland in the years 2001-2019 confirmed their dynamic course. The decrease in demand for potato was accompanied by a sharp reduction in area and harvest, which was partly offset by an increase in yields. The causes of the surface coverage and potato harvest can be seen among others, in decreasing demand for this product, especially in unprocessed form, among Polish communities. Moreover, changes in dietary pattern, lifestyle and the increase in the wealth of Polish society translated into a successive reduction in potato consumption. If Polish consumer reaches for potato products, he chooses processed ones. It gives a decreasing trend of their 
consumption in unprocessed form. The growing consumption of processed potato form (e.g. french fries, potato ready meals) confirms that it is worth continuing the development of production. Although it is especially important to invest in processing.

The regional analysis also showed that the voivodships with the highest acreage for potato cultivation, as well as the harvest, throughout the entire period studied, were Mazowieckie and Łódzkie. The area and collections in these voivodships constituted in the majority of the examined period 2 or even 3 standard deviations from the national average. However, the highest productivity, in terms of yields per hectare, in years 2001-2017, was shown by the Opolskie voivodeship. This part of Poland was above the country average in the whole period considered.

\section{Literature}

Bulletin of hydrological and meteorological services IMGW - PIB from 1983-2017.

Cassady, D., Jetter, K. M., Culp, J. (2007). Is price a barrier to eating more fruits and vegetables for low-income families? Journal of the American Dietetic Association, 107(11), 1909-1915, doi.org/10.1016/j.jada.2007. 08.015 .

Commission of the European Communities, (2007). COMMISSION STAFF WORKING DOCUMENT .The potato sector in the European Union. Brussels, SEC 533. Downloaded on June 2, 2019 from: https://ec.europa.eu/agriculture/sites/agriculture/files/publi/reports/fruitveg/potato/sec533 en.pdf.

Czerko, Z. (2015). Jak przechowywać ziemniaki, stosując integrowaną Ochronę roślin. Ziemniak Polski, 1, 24-30.

Dzieżyc, J. (ed.) (1989). Water needs of crop plants. PWN Warszawa, pp. 419.

Dzwonkowski, W. (2017). Evolution of potato production in Poland and the EU. Problemy Rolnictwa Światowego, 17(3), 71-80.

Głuska, A. (2002). Influence of soil conditions and rainfall distribution on yield and some quality characteristics of tubers as a limitation in organic potato production. Zeszyty Problemowe Postępów Nauk Rolniczych, 489, $165-175$.

GUS, (2018a). Small Polish Statistical Yearbook. GUS, Warszawa.

GUS, (2018b). Statistical Yearbook of Agriculture. GUS, Warszawa

GUS, (2019). Land use and crop area in 2018. Statistical information. GUS, Warszawa.

Haverkort, A.J., MacKerron, D.K.L. (ed.) (2000). Management of nitrogen and water in potato production. Wageningen Pers., Wageningen, pp. 353.

Klusek, G. (2019). Polish Potato Program. Świętokrzyski Portal Rolniczy. Downloaded on June 2, 2019 from: https://www.sodr.pl/swietokrzyski-portal-rolny/aktualnosci/Program-dla-polskiego-ziemniaka-/idn:1018.

Local Data Bank: https://bdl.stat.gov.pl.

MRiRW, (2018). Polish Potato Program. Downloaded on June 2, 2019 from: https:/www.gov.pl/web/rolnictwo/ program-dla -polskiego-ziemniaka.

Nowacki, W. (2008). Irrigation as a factor increasing, stabilizing and improving the quality of potato yield. Wieś Jutra, 2(105), 11-12.

Nowacki, W. (2018). Water in potato production, problems and challenges. Ecological Engineering, 19(6), 14-25, DOI: https://doi.org/10.12912/23920629/95273.

Pastuszewska, T., Pawlak, A. (2006). Potato ring rot, PIORiN, Warszawa, p. 2.

Pedersen, S. M., Bizik, J., Costa, L. D., Coutinho, J., Dolezal, F., Gluska, A. (2005). Potato production in Europe a gross margin analysis. Frederiksberg: Fødevareøkonomisk Institut, Københavns Universitet. Kopenhaga, FOI Working Paper, 5(2005), 1-39.

Petrick, M., Weingarten P. (2004). The role of agriculture in Central and Eastern European rural development: an overview [in:] M. Petrick, P. Weingarten (ed.) The Role of Agriculture in Central and Eastern European Rural Development: Engine of Change or Social Buffer? Institute of Agricultural Development in Central and Eastern Europe (IAMO), 25, 1-19.

Plichta, T. (2019). Potato market. Downloaded on June 2, 2019 from: http://Rynek ziemniaka podr.pl/wp-content/ uploads/2019/04/Rynek-ziemniaka.pdf.

Potato market. Status and prospects (2001-2018). Market analyses by IERiGŻ-BIP, MRiRW, ARR.

Szajner, P. (2018). Market analysis. Potato market. Status and prospects. Zakład Badań Rynkowych IERiGŻ-PIB. Warszawa. 


\section{A.S. Kowalska, K. Gurkowa}

Tuka, P. (2016). Changes in the crop area and profitability of potato production in Poland. Roczniki Naukowe SERIA, 18(3), 363-367.

Zarzyńska, K. Wierzbicka, A., Grudzińska, M. (2016). Organic potato production as a guarantee of its pro-health features. Biuletyn Instytutu Hodowli i Aklimatyzacji Roślin, 279, 77-87.

\section{For citation:}

Kowalska A.S., Gurkowa K. (2019). Changes in Potato Production and Consumption in Poland in 2001-2019. Problems of World Agriculture, 19(3), 46-56; DOI: 10.22630/PRS.2019.19.3.45 